\title{
Lumen
}

Selected Proceedings from the Canadian Society for Eighteenth-Century Studies

\section{Productive Disorientations: The Anomalous Volume 7 of Tristram Shandy}

\section{Dawn Morgan}

Volume 30, 2011

URI : https://id.erudit.org/iderudit/1007716ar

DOI : https://doi.org/10.7202/1007716ar

Aller au sommaire du numéro

Éditeur(s)

Canadian Society for Eighteenth-Century Studies / Société canadienne d'étude du dix-huitième siècle

ISSN

1209-3696 (imprimé)

1927-8284 (numérique)

Découvrir la revue

Citer cet article

Morgan, D. (2011). Productive Disorientations: The Anomalous Volume 7 of Tristram Shandy. Lumen, 30, 61-77. https://doi.org/10.7202/1007716ar

Copyright (C Canadian Society for Eighteenth-Century Studies / Sociéte canadienne d'étude du dix-huitième siècle, 2011
Ce document est protégé par la loi sur le droit d'auteur. L'utilisation des services d'Érudit (y compris la reproduction) est assujettie à sa politique d'utilisation que vous pouvez consulter en ligne.

https://apropos.erudit.org/fr/usagers/politique-dutilisation/ 


\section{Productive Disorientations: The Anomalous Volume 7 of Tristram Shandy}

The epigraph introducing Volumes 7 and 8 in the initial serial publication of Tristram Shandy reads in translation, "For this is not a digression, but is itself the work." ${ }^{11}$ In narrative terms, however, Volume 7 is an excursus from what precedes and follows, and Volume 8 in turn deviates from the digressive norm by finally getting to the long-promised point of Uncle Toby's amours. So the epigraph raises the question: if the fourth installment of Sterne's serially-published novel, comprised of Volumes 7 and 8, is "itself the work," then what are Volumes 1 to 6 and the concluding Volume 9? I wish to address this question by focusing on Volume 7 in particular because, in the context of the rest of the novel, it's such a radical departure, so to speak; it seems to have been

1 Non enim excursus hic eius, sed opus ipsum est." The Florida Edition of the Works of Laurence Sterne: The Life and Opinions of Tristram Shandy, Gentleman, eds. Melvyn New and Joan New, 3 vols. (Gainsville: University Presses of Florida, 1978-84), The Text, II.573. English translation mine. The editors of The Florida Edition provide the context in Pliny the Younger, from which the epigraph is taken. In the source passage, Pliny admonished the writer to stick to the theme of a work as set out in its title. See New et al., The Notes, III.444.

All quotations from Sterne's novel indicate Sterne's volume and chapter, followed by the page numbers of the Florida Edition. Roman numerals refer to The Florida Edition volume numbers only, and are used when citing material outside Sterne's novel proper, such as the epigraph above, which appears on the title page of Sterne's Volume 7, and in the Florida Edition volume II.573 as indicated above. Roman numerals are used also when citing endnotes to the novel, as above, and letters written by Sterne. The endnotes are published as The Florida Edition of the Works of Laurence Sterne, Vol. III, The Life and Opinions of Tristram Shandy, Gentleman, The Notes, eds. Melvyn New with Richard A. Davies and W.G. Day (Gainsville: University Presses of Florida, 1984). The letters are published as The Florida Edition of the Works of Laurence Sterne, Vol. VII: The Letters, Part I: 1739-1764 and Vol. VIII: The Letters, Part II: 1765-1768, eds. Melvyn New and Peter de Voogd (Gainsville: University Presses of Florida, 2009). 
unplanned, but, as I will argue, this does not mean it is accidental or incidental to the overall work. Volume 7 recounts, with a good deal of narrative liberty, the desperate trip to France that Sterne took in 1762 as his consumption worsened, sales of Volumes 5 and 6 flagged, and a hiatus opened between their publication in 1761 and the appearance of 7 and 8 fully four years later in $1765 .^{2}$ Thomas Keymer, in establishing Sterne's skillful exploitation of the imperatives of serial publication for narrative ends, cites a contemporary commentator who wondered, during the wait, if the novel had ended at Volume 6 and readers had seen the last of Tristram after all. ${ }^{3}$ Sterne might well have wondered the same. And when publication was finally continued, Volume 7's straightened narrative line, serious tone, quickened tempo, and selective suspensions of irony were strikingly anomalous in a previously satirical, sentimental, and digressive novel. I find that Sterne made these changes through generic modal shifts, from idyll to picaresque, and from Tristram's fictional autobiography to Sterne's autobiography cast as fiction, as if the roles of author and character had been reversed. The resulting mixture of genres and the emotional responses they produce, far from being anomalous, complement and complete rather than digress from the narrative as a whole. The final generic shift back to the idyll, without irony, that concludes Volume 7, recasts the novel in a surprising and productively disorienting way.

Volume 6 leaves off with a promise, or rather, an aspiration, to proceed, finally, in a straight narrative line through Tristram's own story and that of Uncle Toby. ${ }^{4}$ But while Volume 7 does proceed in an unusually straight line, neither Tristram's childhood story nor Toby's bowling green and courtship story are resumed until Volume 8. Instead, we experience a drastic generic shift that the attentive reader is prepared for only by the narrator's observation on straight narrative lines, that "your men of wit and genius have all along confounded this line ... with the line of GRAVITATION". ${ }^{5}$ Volume 7 then proceeds both to practise and to defy what its author here seems to condemn. The tone suddenly becomes serious and the action moves in a straightened line as the generic mode shifts. Things become grave indeed, as the reader is transported from the pastoral idyll, however ironic, of Shandy Hall

2 Arthur H. Cash, Laurence Sterne: The Later Years (London: Methuen, 1986), 120, 203.

3 Sterne, the Moderns, and the Novel (Oxford: Oxford University Press, 2002), 140.

$4 \quad 6.40 .570$.

$5 \quad 6.40 .572$. 
and the bowling green, to a picaresque excursus of adventures on the road through France. In the process, Tristram's fictional autobiography becomes Sterne's autobiography - a factor that problematizes Pliny the Younger's advice evoked by the epigraph, "to stick to the theme of a work as set out in the title" (see note 1 above). So what or who is Tristram Shandy about? The medical histories of narrator and author converge and move to the surface, and the freshly resumed novel develops "in improvised response to the ungovernable rhythms and crises of its author's own health." ${ }^{\prime 6}$ The shift from idyll to picaresque introduces a whole new range of emotional effects. Whereas the rest of the novel is characterized predominantly by satire and sentimentality, Volume 7 is marked by serious fear and anxiety. The "exuberant joke" of the unmanageable text of the earlier volumes "gives way to panic." ${ }^{7}$ Satire and sentimentality are overwhelmed by a sense of gravity about the writer's flight from death, a gravity and flight represented in the volume by speed and narrative directness and linearity, a quickened tempo and an unprecedented sticking to the point. Such fear and panic are not present and, indeed, are generically excluded from the novel outside Volume 7. So Volume 7 enables affect that the rest of Tristram Shandy does not and cannot accommodate. ${ }^{8}$ It is grounded in Sterne's actual situation and real feelings, above all the very real fear of death, which leads to the frenetic journey through France to the salubrious climate of Languedoc.

The narrator's journey is related only tangentially to the actual journey Sterne made in 1762, though he described Volume 7 in a letter as "a comic account of my journey from Calais thro' Paris to the Garonne." ${ }^{\prime 9}$ The events depicted are integrated into the rest of the novel in the sense

6 Keymer, Sterne, the Moderns, and the Novel, 145, 147. Keymer distances himself from earlier readers of Tristram Shandy, such as Wayne C. Booth, who tend to conflate "Sterne's design and project with Tristram's" but he does take into account the "closeness with which Tristram's condition tracks Sterne's over the years of the serialization," which Keymer believes "suggests the relationship was causal" (147). On Keymer's address of Booth, see 143-144. Also see Booth, "Did Sterne Complete Tristram Shandy?", Modern Philology 48 (1951), 172-83.

7 Sterne, the Moderns, and the Novel, 136.

8 A dark glimpse of death-as-pursuer does appear after Volume 7 in a brief reference to the pulmonary haemorrhage suffered by Sterne while travelling in France; the account is characteristically combined, within a single sentence, with an account of nearly bursting a blood vessel from laughing (8.6.663).

9 Lewis Perry Curtis, Letters of Laurence Sterne (Oxford: Clarendon Press, 1935), 234 and New, Letters, Part I, VII. 399. 
that the flight involves incidents and encounters of a comic nature, but this does not disguise the motive for the journey that is the basis of the material and transformations of affect in Volume 7. Indeed, the line of gravitation, or what Sigurd Burckhardt has identified as the "law of gravity" in Tristram Shandy, operates as a sustained pun. ${ }^{10}$ Both the literal or physical meaning of "gravity," as in the law identified by Isaac Newton of the force that pulls bodies and matter downwards, or makes them fall, and the word's metaphorical sense of seriousness, operate in ambiguous tandem throughout the picaresque journey. This is in contrast to the dominance, elsewhere in the novel, of the first, literal meaning of "gravity," where such things as mortars, sash windows, and hot chestnuts invariably "plummet" to the genital area, leading readers along the dirty road of profane interpretation, ${ }^{11}$ and where the second, metaphorical sense is disparaged as "the target of Yorick's enmity and Tristram's nose-thumbing."

My proposal is to read Tristram Shandy in light of this gravitational pull of seriousness - to propose Volume 7, as the epigraph suggests, as the lens through which to read the novel as a whole. I find that Volume 7 complements and completes the novel in a particular way by reversing the established values of earnestness and jest, further threatening the reader's precarious balance in an already ethically and pathetically vertiginous work. Whereas previously in the novel, death is comically rendered and philosophically distanced, Volume 7 suddenly takes it quite seriously and brings it up close. The sudden dead-seriousness is striking, and the gloom only lets up with a second, rather more subtle shift of genre and affect in the Volume's final chapter, when the irony predominant elsewhere dissipates. For a brief moment, the themes of impotence or castration are themselves cut off, and the idyll that is restored is surprisingly unequivocal, free of irony, and sincerely joyful. The reader, conditioned and even jaded, by this time, to the work's wicked dark humour, scarcely knows what to make of this moment of truth and may not even recognize it as evidence that "Sterne's final

10 Sigurd Burckhardt, "Tristram Shandy's Law of Gravity," ELH 28/1 (March 1961): 70-88.

11 Burckhardt, 72 .

12 Burckhardt, 70. Yorick's hostility is directed to affectations of gravity, where "it appeared a cloak for ignorance, or for folly" (1.11.28-29); in this passage, Yorick quotes Rochefoucauld to define gravity as "A mysterious carriage of the body to cover the defects of the mind" (Notes III.70 n. 28-29). 
joke" turns out to be "that he is not joking."13 In this new light, Volume 8 proceeds more or less directly to the story of Toby's love affair. Paradoxically, Tristram's early claim that his autobiography is "wrote ... against the spleen"14 is borne out by Volume 7 as it proceeds in all seriousness to suspend momentarily Tristram's sad narrative of bodily losses in a brief vision of wholeness despite (or including) those losses. For an instant, the past becomes imaginatively present, or we could say the text locates the present moment, and in so doing, successfully projects a future. We get what is perhaps a glimpse of the alternative Tristram Shandy that Sterne may once have had in mind:

Sterne said that his first Plan, was to travel his Hero Tristram Shandy all over Europe, and ... finish the work with an eulogium on the superior constitution of England and at length return Tristram well informed and a compleat English Gentleman. ${ }^{15}$

Keymer locates the ultimate source for the incremental increase of seriousness in the novel's preoccupation with loss, "including the large scale human losses of global war that formed an ongoing backdrop ... until 1763." ${ }^{16}$ So where Keymer sees the seriousness as caused by loss, I find that Sterne's seriousness suspends the novel's sense of loss. The difference is between views of the novel as pessimistic or optimistic. Keymer's conclusion arises from his overall project to restore Sterne's novel to its historical context of eighteenth-century modernity and the emergence of the novel, a project that requires rescuing it from the two previously dominant and competing critical approaches, both of which are anachronistic. One views Tristram Shandy as "proto-postmodernist" or "purely proleptic" of postmodernist concerns, with its critique of the novel form that was only then coming into being and achieving discursive authority. The other approach views Tristram Shandy as a belated but "willful Renaissance throwback" to the satirical tradition of learned wit, a work that therefore displays a marked disregard for developments, literary or otherwise, of its own historical period. ${ }^{17}$

13 Burckhardt, 71.

$14 \quad 4.22 .360$.

15 John Croft, "Anecdotes of Sterne," Whitefoord Papers, W.A.S. Hewins, ed. (Oxford: Oxford University Press, 1898), 228. Qtd. in Keymer, Sterne, the Moderns, and the Novel, 147.

16 Sterne, the Moderns, and the Novel, 165.

17 Sterne, the Moderns, and the Novel, 5-6. 
In the process of situating Sterne's novel within its own historical milieu, Keymer identifies contemporary intertexts as key "in unlocking and developing, in the middle and later instalments of Tristram Shandy, the melancholy possibilities always inherent in the work's fixation on incommunicable and irremediable pasts," which he cites as the source of the "gloomy undertow" that moves to the surface of the later volumes. ${ }^{18}$ The present analysis concentrates on the exploration of melancholy possibilities arising not from external contexts but from the physicality or materiality of language, the very substance of the Life and Opinions, and the resultant "unmentionable mystery of the word, ${ }^{\prime 19}$ the problem that words are both concrete things and signifiers of abstractions. Tristram and Toby are bedeviled by this duplicity that is also Sterne's problem as he struggles to set pen to paper while fleeing for his life. Uncle Toby represents avoidance of the problem by attending only to things, and whistling Lilla-bullero when avoidance fails. Tristram, like Sterne, concocts his story precisely by exploiting linguistic ambiguity and reveling, ultimately, in how excellent it is that language is such an unstable, malleable thing. Generic shifts and correlative changes in pathos follow from his grasp of "many-handled" words, or words whose meaning resonates in many different directions, as in the pun on "gravity" and "gravitation," and whose multiple meanings productively suspend the reader between earnestness and jest, between the grave and the comically creative.

Keymer holds that the novel escapes being overwhelmed by "the pessimism towards which it tends ... by appealing to the reader's imaginative involvement" in reconstituting and sustaining the past in the present. ${ }^{20}$ While not disputing this enlistment of the reader, which is everywhere in evidence, I argue that Tristram Shandy, just as it embraces the instabilities of language, so also puts its pessimism to work quite practically in Volume 7, in ways that enable this novel, elsewhere thoroughly entangled and mired in the past, to locate the present moment, however briefly. This access is the basis of my evaluation of the novel as a whole as optimistic, despite and including Volume 7. The close of Volume 7 presents a proleptic glimpse of Tristram's final scene in Volume 9 with Maria of Moulines and her goat. ${ }^{21}$ In Mark Loveridge's analysis,

19 Burckhardt, 77.

20 Sterne, the Moderns, and the Novel, 183. 
the Maria scene produces a highly productive suspension of irony that carries over into Yorick's concluding pronouncement on what this story is about ("A cock and a bull ..." ). ${ }^{22}$ Loveridge notes the "communal quality" of the novel's conclusion, its sense of shared "authority and influence" as each character comments on the joke, on the preceding narrative, on each other's views, and so on, in support of his argument that the figure of the cock and bull forms "a sufficient poetic closure to the novel."23 Volume 7 ends with a similar vision of community, both joyfully carnal and serious, at a disorienting intersection of the high and low roads in a novel that usually depends utterly on their divergence. En route to this vital intersection, Volume 7 is first drawn into death's orbit.

Representations of death in the early parts of the novel are primarily comic and sentimental, in contrast to death's seriousness in Volume 7. Sterne's autobiographical fear and panic, which register so strikingly there, are not in evidence in the treatment of the deaths of Yorick, Aunt Dinah, Bobby, or Le Fever in previous volumes. ${ }^{24}$ The death of Yorick in Volume 1 is thoroughly comic, and even carnivalized in the sense that, although he dies broken-hearted, he triumphs in thereby "giving his enemies the slip forever" ${ }^{25}$ He then continues to appear throughout the novel in carnivalesque fashion, and even has its last word, generating through laughter the overcoming of death. The death of Dinah is flatly noted and understated, pointedly without pathos, just as she is silenced and sidelined in life. The incident and significance of her death lies solely in the question of what to do with her legacy: the pros-

22 Loveridge, Mark, "Stories of Cocks and Bulls: The Ending of Tristram Shandy." Eighteenth Century Fiction 5/1 (Oct 1992): 35-54.

23 Loveridge, 54; 36n.5.

24 Other deaths briefly touched on in the novel but not discussed here are those of Trim and Toby (6.24.544-45), both of which are sentimental vignettes, and the reference to the death of Le Fever's wife in bed, which serves the satirical castrationimpotence theme (6.7.507).

25 1.12.33. R.F. Brissenden concedes that the portrait of Yorick's death is "sketched humorously," but notes a difference in tone even of this early, comic death: "The tone of the whole section is markedly different from the tone of the surrounding chapters - the style in general is more formal, more even and more restrained than it is elsewhere in Volume 1; it seems as if Sterne is at last trying to tell a straight story ... the humour is of the grave, realistic, Cervantic sort." See "Trusting to Almighty God: Another Look at the Composition of Tristram Shandy," The Winged Skull: Papers from the Laurence Sterne Bicentenary Conference. Arthur H. Cash and John M. Stedmond, eds. (London: Methuen, 1971), 263-4. Qtd. in Lawlor, 161. 
pect of spending it distracts Walter from the catastrophe of Tristram's truncated name to the question of whether to use the money to send Bobby on a Grand Tour, or to improve the Oxmoor pasture. ${ }^{26}$ Bobby's precipitous demise shortly thereafter similarly distracts Walter, but this time from his calculations of the cost of the Grand Tour. ${ }^{27}$ His grief takes the form of an emotionally-distancing philosophical eloquence. ${ }^{28}$ The resultant indirection and comic incorporation of Bobby's death - the Bobby who has no life in this text until he dies - is extended and emphasized through its downstairs version, consisting of Trim's repeatedly interrupted oration. ${ }^{29}$ Tristram as narrator comments on the death of his brother only to announce its significance as the point from which "properly ... the story of my life and opinions sets out" ${ }^{30}$ Until that point, Tristram is, like Uncle Toby, a younger son who would have to make his way in the world. With Bobby's death, he becomes heirpresumptive to a landed estate and thereby gains full personhood in a hierarchical, patriarchal society — but for his nose and name.

So in the household as a whole, the death of Yorick is overcome by laughter, and the deaths of Dinah and Bobby are buried under loads of rhetoric and financial calculation that render the sentiments of grief selfinterested and hypocritical. The death of Le Fever was the sentimental highlight for eighteenth-century readers, but its sentimentality too is undercut with satire in the representation of the death as a sequence of seemingly interminable, and therefore comic, physiological effects:

Nature instantly ebb'd again, - the film [over Le Fevers' eyes] returned to its place, - the pulse fluttered - stopp'd - went on - throb'd - stopp'd again - moved - stopp'd - shall I go on? - No. ${ }^{31}$

Keymer identifies a "failure of feeling" typical of Sterne in such undercutting, and consistent with contemporary skepticism and a "backlash against sensibility" evident in commentary by Henry Mackenzie as well as by Mary Wollstonecraft, Hannah More, and others. Sterne's A Sentimental Journey, for example, like Tristram Shandy, "fails, or refuses, 
to sustain any clear distinction between sentimental sincerity and Shandean satire," thus "allowing sentiment and satire to coexist and compete throughout the text, and allowing readers to consume it according to either rubric." The taste for the sentimental is thereby "simultaneously fed and mocked." ${ }^{32}$ While I agree with Keymer that Tristram Shandy generally does so move between satire and sentimentality, and with the effects cited, the present reading differs from Keymer's in addressing the intrusion of a mixture of truly serious affect - fear and panic with unalloyed and non-ironic joy, as we shall see below.

In all of these representations of death, the reader is nowhere prepared for the sudden seriousness of its treatment in Volume 7, in which headlong haste contrasts maximally with the narrative zig-zaggery and delay of the other volumes in their comic incorporation and diminution of death. In Volume 7, by contrast, fear and panic are generated by the orchestration of events with a linearity and speed that mutually reinforce each other: the inability to avoid or digress from the topic or figure of death, unlike with the earlier comic encounters, is thematized by the uncharacteristically straight narrative line adumbrated at the conclusion of Volume 6 . And the straight narrative line intensifies the inescapability of death. The speed of events multiplies encounters with the figure of death, and compounds collisions - elsewhere celebrated in the novel - between external, or the "objective time" of Sterne's composition of the text, and "factitious, fictitious," or represented time in which narrated events take place. ${ }^{33}$ Jean-Jacques Mayoux has noted the predominantly comic representation of such disturbed time relations prior to Volume 7. Tristram appears as a "skillful clown" who is "perplexed, tangled even, by difficulties he himself creates" in arranging his narrative such that, for example, thirty-three pages of text intervene in the famous scene, in Volume 2, between the time when Uncle Toby takes his pipe from his mouth and when he begins to speak. The time lapse is not in the story but in its telling, and through such interruptions, Sterne keeps the reader ever mindful of such time-sense inter-relations. But in much of the novel, as in this example, comic despair over getting the writing abreast of the living - and stopping the action of living to

32 Thomas Keymer, "Mackenzie, Sterne, and The Failure of Feeling," Literary Sinews: Essays in Honour of Bjorn Tysdahl. Jakob Lothe, Juan Pellicer, and Tore Rem, eds. (Oslo: Novus, 2003), 38-39, 40.

33 Jean-Jacques Mayoux, "Variations on the Time-sense in Tristram Shandy," The Winged Skull: Papers from the Laurence Sterne Bicentenary Conference. Arthur H. Cash and John M. Stedmond, eds. (London: Methuen, 1971), 3. 
make time and space for the writing — is playful and jesting, ${ }^{34}$ whereas in Volume 7, comic despair turns to anxiety and even anguish that at times nearly overwhelms the narrative.

The change in mode from the ironized idyll of the previous volumes to the picaresque adventures on the road is made, first, by the extrication of the narrator, Tristram, from Shandy Hall and the family context that supplies and supports his identity. In the first chapter of Volume 7, Tristram is named as the narrator when he is addressed by Eugenius, the interlocutor of Yorick on his deathbed in Volume 1. On hearing about Tristram's close call — about Death knocking at his door and Tristram's greeting, followed by his turning Death away with feigned light-hearted indifference - Eugenius obligingly supports Tristram's decision to fly for his life, and with that, the narrator is off "like a cannon," landing in Dover before the end of the chapter. Accustomed as the reader now is to the narrative's dawdling and delay, it comes as a shock to find also, by the second chapter, that the narrator is already on board a ship and crossing over to France. But this narrator, who, upon asking the ship's captain, "is a man never overtaken by Death in this passage?" immediately falls seasick, and who resolves to face his pursuer "full in the face ${ }^{\prime 35}$ - this narrator is not named Tristram again until much later in Volume 7, and only when death is finally given the slip. The omission marks the dislodging of Tristram by Sterne, who wrote, in a letter of 1765, of flying from death through France, ${ }^{36}$ and the overtaking of the fictitious time of the narrative by the objective time of the writing of the novel.

Clark Lawlor has commented on the novel's colliding time-senses, which among other significances, enable the speeding up of the narrative to what he calls "consumptive time" - irregular and disorderly, a structuring of time that imitates the progress of the disease from which Sterne suffered, as understood by contemporary medical science. By means of this "consumptive time," Sterne located the actually openended and unpredictable present, the time he might have available to complete his novel. ${ }^{37}$ Drawing on eighteenth-century medical sources

34 Mayoux, 14.

$35 \quad 7.2 .578$.

36 Curtis, Letters of Laurence Sterne, 257 and New, Letters, Part II, VIII. 454.

37 Clark Lawlor, "Consuming Time: Narrative and Disease in Tristram Shandy," Laurence Sterne's Tristram Shandy: A Casebook. Thomas Keymer, ed. (Oxford: Oxford University Press, 2006), 158. 
on the disease of consumption, Lawlor isolates the two forms of consumption that correlate with two distinct time-senses: the chronic, slow consumption, which lends itself to the good Addisonian or well-prepared-for death, and the acute, galloping kind marked by haemorrhage of the lungs, which Sterne experienced intermittently with his chronic symptoms. ${ }^{38}$ The galloping time and form of consumption is thematized and dominates in Volume 7, as the narrator includes himself, for example, with those who, for more expedition, "wrote-galloping" on passing through Calais. ${ }^{39}$ But consumption was Sterne's disease, not Tristram's, at least not initially, and this pun on what was called "the galloping consumption" is similarly Sterne's and not Tristram's.

The quickened tempo of Volume 7 is elsewhere accomplished by such devices as the subordinate clause by which the narrator enters and seems to depart from Calais in the opening sentence, "Now before I quit Calais ... '"'; ; ${ }^{40}$ and the breathless catalogue of things, seemingly recounted in the moment, that his subsequent flight from Chantilly leaves no time to write about:

No; - I cannot stop a moment to give the character of the people - their genius - their manners - their customs - their laws - their religion - their government - their manufactures - their commerce - their finances ... . I must away — the roads are paved - the posts are short - the days are long - tis no more than noon - I shall be at Fontainebleau before the king- ${ }^{41}$

Speed registers also through external views of the narrator, such as is provided at Boulogne, where he meets the townspeople but dashes off abruptly, leaving the locals to speculate on the possible reasons for his hurry, whether high treason, murder, a woman, or debt. The narrator defends himself against the last charge (despite being long gone by the time we read it) by sticking to the straight narrative line of his flight from death:

I have no debt but the debt of Nature, and I want but patience of her, and I will pay her every farthing I owe her - How can you be so hard-hearted, Madam, to arrest a poor traveller going along without molestation to any one, upon

39 7.4.580.

$40 \quad 7.4 .579$.

$41 \quad 7.19 .604$. 
his lawful occasions? do stop that death-looking, long-striding scoundrel of a scare-sinner, who is posting after me - he never would have followed me but for you - if it be but for a stage, or two, just give me the start of him, I beseech you, madam-. ${ }^{42}$

This increasingly grave and pleading tone, and uncertainty about the outcome of the flight from death, never mind completion of the story about that flight, continues in the narrator's statement of his gloomy preference for death in France among strangers, mediated by cash for services rendered - as may have seemed increasingly likely to Sterne on a few occasions. Rather than watch the suffering of friends who would be at his bedside at home, he states autobiographically: "Was I in a condition to stipulate with death, as I am this moment with my apothecary, how and where I will take his glister - I should certainly declare against submitting to it before my friends ... . [I]n an inn, the few cold offices I wanted, would be purchased with a few guineas, and paid me with an undisturbed, but punctual attention". ${ }^{43}$

The speed and linearity of the narrative line facilitates the fading of Tristram's narratorial mask to reveal its identity with Sterne. The distinction between the two is both marked and confounded in the several often-noted grammatically compromised passages, in which the two faces of the narrator at once disaggregate and cross paths by means of temporal-grammatical disjunctions. In the account of leaving Chantilly, the narrator pronounces spleen as "the best principle in the world to travel speedily upon". ${ }^{44} \mathrm{He}$ makes this pronouncement in the past tense: "upon leaving Chantilly, I declared ... ." Immediately following, he switches to the present tense, as if to say: Now with the (past) experience of that journey, I add "that though [with spleen] you do get on at a tearing rate, yet you get on but uneasily to yourself at the same time" ${ }^{45}$ The disjunction in tense emphasizes the collision of time-senses and narrators that is squarely faced mid-volume, where the text becomes explicit about the linkage of Tristram's fictional autobiography to Sterne's historical autobiography presented as fiction. In Chapter 27, for example, Tristram finally reappears in his Shandy family context

43 7.12.591-2. The Florida edition provides the literary tradition that Sterne draws on for these sentiments, a tradition that includes Burnet, Cicero, and Montaigne. See Notes, III.459n. 591.9-592.9.

$44 \quad 7.19 .604$.

$45 \quad 7.19 .604$. 
when the narrative suddenly touches on what should be the subject matter of Volume 7: Tristram's Grand Tour. But we find it has already taken place. It is now only remembered and will be written about only in the future. Sterne and Tristram seem to catch up with each other in the next much critically discussed chapter:

Now this is the most puzzled skein of all - for in this last chapter, as far at least as it has help'd me through Auxerre, I have been getting forwards in two different journies together, and with the same dash of the pen - for I have got entirely out of Auxerre in this journey which I am writing now, and I am got halfway out of Auxerre in that which I shall write hereafter ... . I have brought myself into such a situation, as no traveller ever stood before me; for I am this moment walking across the market-place of Auxerre with my father and my uncle Toby ... and I am this moment also entering Lyons with my post-chaise broke into a thousand pieces - and I am moreover this moment in a handsome pavillion ... upon the banks of the Garonne ... where I now sit rhapsodizing all these affairs.

- Let me collect myself ..... ${ }^{46}$

The two faces of the narrator are identified and differentiated by such means, and their recollection of each other produces both clarity and comedy about the seriousness and altered stakes of Volume 7 . The prominence of the temporal-grammatical disjunctions, with the consequent intrusions of Sterne's tragic autobiography, is key to the claim that Volume 7 is itself the work, because shifts in time-sense have generic significance, and mixtures of genre have chronotopic implications and effects. ${ }^{47}$ The fear and panic that predominate in Volume 7 cast a pall over satire and sentimentality alike through the entire work, rendering it thoroughly mixed generically, and thereby making it absolutely novel, that is, a characteristic exemplar of the modern incarnation of the genre.

The integral linkage of time or "time space" ${ }^{\prime 8}$ with genre is itself thematized when the narrator encounters the Ass stranded over the

46 7.28.621-2. The Florida editors identify this passage as "the single most discussed incident in Tristram Shandy among twentieth-century critics. See Notes, III. 477n. $621.16 \mathrm{ff}$.

47 M.M. Bakhtin, "Forms of Time and of the Chronotope in the Novel," The Dialogic Imagination: Four Essays. Michael Holquist, ed. Caryl Emerson and Michael Holquist, tr. (Austin: University of Texas Press, 1981). 84-258. 
threshold of the inn at Lyons. ${ }^{49}$ The awkward threshold situation, to which the narrator is sympathetic, is indicative of transformation, and occasions Volume 7's final generic shift back to the idyll. The ass is, I think, an intertextual allusion to the mode of composition of The Golden Ass of Apuleius, the narrator of which, Lucian, is described in the opening paragraph as adopting a compositional technique likened to a performance by a circus rider leaping from horse to horse, or from tale to tale and genre to genre, apparently randomly, but actually within an overall design. ${ }^{50}$ Lucian strives throughout to transform himself back into human form, a metamorphosis that correlates with a correspondingly drastic change of genre at the narrative's conclusion, with the intervention of the goddess Isis in the young man's sordid adventures. All this is a model for the very different but functionally analogous resolution of Sterne's Volume 7. Sterne's narrator identifies and even communes with the stranded ass at Lyons and shortly thereafter, having abandoned the post-chaise and the river-boat as modes - genres - of travel, proceeds more slowly by mule, gathering the digressive and cheerful "Plain Stories" that, like the story of Tristram's Grand Tour, never appear in the text. But the alteration of genre that correlates with the slower mode of travel itself signals the changed conditions of Sterne's escape from death and therefore successful completion of the Volume:

I had now the whole south of France ... to traverse upon my mule at my own leisure - at my own leisure - for I had left Death, the lord knows — and He only — how far behind me - "I have followed many a man through France, quoth he - but never at this mettlesome rate" - Still, he followed, - and still I fled him — but I fled him chearfully — still he pursued - but like one who pursued his prey without hope - as he lag'd, every step he lost, softened his looks — why should I fly him at this rate?

50 Apuleius, The Golden Ass. P.G. Walsh, tr. (Oxford: Oxford University Press, 1994), 1. The form of tale-telling is referred to as "Milesian" by the central character, Lucian. The Florida edition editors do not identify this allusion, but the form of the "Milesian tale" and "the Apuleian influence has long been recognized" in one of Sterne's main literary sources, Miguel Cervantes's Don Quixote (1605), which incorporates "a great deal of self-conscious play with notions of wise donkeys ... and asininely foolish humans." See Robert H.F. Carver, The Protean Ass: The Metamorphoses of Apulieus from Antiquity to the Renaissance (Oxford: Oxford University Press, 2007), 375-376. 
So ... I changed the mode of my travelling once more ... . ${ }^{51}$

The successful completion of the distinctive Volume 7 is also the aesthetic completion of the entire novel, in that Volume 7 contrasts with and complements the satirical and sentimental drollery of the other volumes, establishing the modern basis of the novel as the genre of mixed feelings - not the aestheticized range of feeling isolated in the novel of sentiment and ironized by Sterne, but the inextricable mixture of laughter and death productive of the acutely ambivalent capacity for affect that distinguishes the novel as the modern incorporation of carnival. Volume 7 completes the work as an instantiation of the laughteragainst-death process described by Bakhtin in his reading of Rabelais. ${ }^{52}$ The opposition of laughter and death, implicit elsewhere in the novel, becomes explicit in Volume 7. Irruptions of Sterne's autobiographical flight into Tristram's world, spurred by the galloping consumption, effectively conjoin and oppose these affective states that in other genres uneasily co-exist. Tristram is not merely joking when he writes at the outset of Volume 7, before generically disappearing, "I have forty volumes to write, and forty thousand things to say and do ... and as thou seest [death] has got me by the throat (for Eugenius could scarce hear me speak across the table) $)^{\prime \prime}{ }^{53}$ Likewise, Sterne wrote to his earliest patron when he sent along the first volumes, "it was every word of it wrote in affliction; \& under a constant uneasiness of mind. Cervantes wrote his humourous Satyr in a Prison — \& Scarron his, in pain \& Anguish - Such Philosophers as will account for every thing, may explain this for me." ${ }^{54}$

Perhaps the most persuasive evidence, finally, that Volume 7, far from being anomalous, completes and therefore constitutes the work is its transformation of the novel's castration-impotence theme. First introduced as interruption in the opening scene of the conception of the hero, the theme is elaborated through progressive (or digressive) displacements, from the wound in Uncle Toby's groin to Tristram's crushed nose-that-is-pointedly-not-a-penis, his accidental circumcision

$51 \quad 7.42 .645-6$.

52 Rabelais and His World. Hélène Iswolsky, tr. (Bloomington: Indiana University Press, 1984), 272.

53 7.1.576.

54 Quoted in Cash, The Later Years, 2 and printed in the same volume in Appendix 1: Unedited Sterne Letters, 360. The letter has since been printed without editorial changes to the passage quoted in The Florida Edition ... Letters, VII.107-108. 
from a falling window sash, and his sadly truncated (cut off) name. We could say that this theme mediates between laughter and death in Sterne's novel like a hinge. Volume 7's extended version of castration is the ultimate interruption: that of being cut down or cut off by death mid-text, or in the middle of one's story. This is the significance and aptness of Thomas Patch's "Caricature of Laurence Sterne and Death," painted in 1765-66. ${ }^{55}$ Patch's use of the image of Sterne, rather than Tristram, sums up Volume 7 pictorially and emblematically, which is Sterne's face to face confrontation with death. But the theme of castration and of being cut down by death are themselves displaced in the final generic return to the idyll, as the narrator slows down and ambles on his mule across the plains of Languedoc. We find he has given not just death but also the castration theme, or the threat of castration, the slip. When the mule "makes a dead point," refusing to continue, the narrator leaps "off his back ... kicking ... one boot into this ditch, and t'other into that ${ }^{\prime \prime}{ }^{56}$ dismounting as well what Arnd Bohm refers to as the "unnatural conjugations" of language and desire that the mule stands in for. ${ }^{57}$ For this idyll, unlike that of Shandy Hall and the bowling green, is non-ironic, and thoroughly erotic. It suspends the castration theme, while at the same time invoking it through the narrator's preoccupation with the slit in Nannette's petticoat. Nannette is "a sun-burnt daughter of Labour" among the peasants "preparing for a carousal" that the narrator joins. ${ }^{58}$ Nannette is, in fact, the positive and productive counterpart of the frustrated, sterile Widow Wadman, the female correlate of male castration and impotence in the volumes that follow 7. The slit in Nannette's petticoat is both a metaphor and a metonymy of the vaginal slit, an image that signifies the absence of the penis but also the opening to procreation, to productive conjugal relations. This is yet another striking difference between Volume 7 and the rest of the novel in which castration and impotence prevail. Volume 7 ends with Tristram-Sterne joining the erotic pastoral and partaking of all the unequivocally joyful activities that gesture toward success-

55 Lawlor, 165 n.25. Patch's work is described in detail by Cash, Laurence Sterne: The Early and Middle Years. (London: Methuen, 1975), 310-11.

56 7.43. 649 .

57 Arnd Bohm, "Unnatural Conjugation in Tristram Shandy, Book VII," 1650-1850 15 (2008): 107-54.

58 7.43.649. The Florida edition editors compare a similar scene of combined vegetable, animal, and human fecundity in Sterne's A Sentimental Journey. The passages are compared in the Notes III.494n.646.12-13. 
ful heterosexual coupling and resolved sexuality. ${ }^{59}$ So while Volume 7 thus stands outside the novel in its development and in its conclusion, it is itself the work in dropping the irony and finally treating in earnest what elsewhere, in preceding and subsequent volumes, can only be treated in jest.

DAWN MORGAN

St. Thomas University 